DOI: 10.17805/trudy.2016.5.3

\title{
ГЕНДЕРНЫЕ СТЕРЕОТИПЫ КАК ПРЕДМЕТ ДИСКУССИИ СТУДЕНЧЕСКОЙ МОЛОДЕЖИ
}

\author{
Н. А. Селиверстова \\ (Московский гуманитарный университет)
}

\begin{abstract}
Аннотация: В статье рассматривается опыт организации практических занятий по теме «Культура как фактор социальных изменений» в рамках вузовской дисциилины «Социология». В ходе занятий преподаватель фиксирует изменение гендерных стереотипов в отношении социальных ролей женщины и мужчины.
\end{abstract}

Ключевые слова: студенческая молодеж; гендерные стереотипы; социальные нормы; дискуссия

\section{GENDER STEREOTYPES AS A SUBJECT OF DEBATE AMONG STUDENT YOUTH}

\author{
N. A. Seliverstova \\ (Moscow University for the Humanities)
}

\begin{abstract}
The article discusses the seminars on "Culture as a factor in social change" as part of the university course in sociology. At the seminars, the professor noted the change in the use of gender stereotypes referring to male and female social roles.

Keywords: student youth; gender stereotypes; social norms; discussion
\end{abstract}

Гендерные стереотипы в последние два десятилетия привлекают внимание многих отечественных исследователей. Однако это не только предмет исследовательского интереса. В системе высшего образования подготовка бакалавров по направлению «Социальная работа» включает курс «Гендерология и феминология» (Петрова, 2010). Бакалавры других направлений подготовки имеют возможность в дисциплине «Социология» обсудить проблематику гендерных стереотипов, которая включена в тему «Культура как фактор социальных изменений».

Социология как учебная дисциплина помогает студентам «подняться» над собственным жизненным опытом, перейти от понимания социальной реальности на уровне здравого смысла к научному объяснению; увидеть «себя в обществе» и «общество в себе»; осознать практическую значимость социологии в будущей профессиональной сфере, научиться вести дискуссию. 
Исходя из опыта преподавания социологии можно заметить, что наиболее часто дискуссии возникают в ходе обсуждения темы «Культура как фактор социальных изменений». Ход занятий, задания по данной теме, выполненные студентами-психологами Московского гуманитарного университета в 2003-2004, 2004-2005 и 2013-2014 уч. гг. и анализируются в статье. На семинарские занятия по названной теме учебно-тематическим планом отводится 4 часа.

Ход занятий таков. После обсуждения теоретических вопросов и некоторых проблемных ситуаций студентам предлагается прослушать маленький рассказ и выполнить практическое задание. Этот рассказ известен большинству преподавателей, но напомнить его в рамках статьи необходимо.

«Жила-была одна девушка, звали ее Абигайл. Она жила около реки, в которой кишмя кишело крокодилами. На другом берегу реки жил Грегор. Они были влюблены друг в друга, все время тосковали и хотели увидеться. К несчастью, во время непогоды был разрушен маленький мост, поэтому им было очень трудно встретиться.

Абигайл почти умирала от тоски. Поэтому она пошла к рыбаку Синбаду, у которого была единственная во всей округе лодка. Она рассказала ему о своей ситуации и попросила перевезти ее через реку. Синбад согласился, но с одним условием. Абигайл должна была провести с ним ночь.

Абигайл была возмущена этим предложением, т. к. она Синбада не любила. Она отклонила дерзкое предложение Синбада и пошла искать других людей, которые могли бы ей помочь. Она просила людей о помощи, но никто не мог ей помочь.

Разочарованная она вернулась домой к своей матери и рассказала ей о своих тщетных попытках и о предложении Синбада. Она обратилась к матери за советом. Мать ответила: “Смотри, Абигайл, ты уже взрослая девушка. Ты сама должна знать, чего ты хочешь и должна самостоятельно принимать решения”. Сказала это и пошла по своим делам.

Абигайл долго думала. В конечном итоге она решила принять предложение Синбада, т. к. она непременно хотела увидеть Грегора. Она провела ночь с Синбадом. Он выполнил свое обещание и на следующее утро перевез ее на другой берег реки.

После нескольких счастливых часов с Грегором у Абигайл появилась потребность рассказать Грегору о том, что произошло. Когда он выслушал историю, то пришел в ярость: “Что ты сделала? Я не могу поверить, что ты это сделала! Ты провела ночь с Синбадом! Между нами все кончено. Забудь меня! Я не хочу больше тебя видеть!”

В отчаянии пошла Абигайл назад, громко плача. По дороге она встретила молодого парня по имени Джон и рассказала ему о своем горе. Джон 
выслушал ее с большим возмущением и рассерженный пошел к Грегору, чтобы поколотить его.

Абигайл последовала за ним, посмотрела издали и начала смеяться» (Практикум по социологии, 2000: 30-31).

Этот нелепый рассказ с искусственно усложненным сюжетом студенты воспринимают, как правило, с улыбкой или усмешкой. Но позже, выполняя практическое задание, они напрочь забывают о своей первой реакции, обсуждают тему предельно серьезно.

В группах по 3-5 человек студентам предлагается составить своеобразный рейтинг персонажей (от лучшего к худшему) и определить ценности, которые каждый из них олицетворяет.

На следующем этапе представитель каждой группы сообщает о результатах обсуждения и вносит их в таблицу на доске. И, хотя студенты принимают задачу выработки единой позиции группы, на практике она достигается с трудом и не всегда.

За годы периодического использования этого задания каждый из персонажей рассказа занимал позицию от 1 до 5 . Абигайл чаще других удостаивалась как первого места, так и пятого. Скорее всего, данный факт объясняется количественным преобладанием девушек среди студентовпсихологов МосГУ. Визуальное отображение результатов обсуждения рассказа студентами отражает естественную противоречивость в сфере принятия неформальных норм и способствует продолжению дискуссии.

Абигайл, по мнению абсолютного большинства студентов, олицетворяет такую ценность как любовь, при этом на пятой позиции она всетаки иногда оказывалась. Активность Абагайл одобряется большинством, как уже было сказано, большинством девушек. Меньшая часть осуждает Абигайл. Наиболее распространенное мнение этой части студентов сводится к следующему суждению: «Что это за любовь, если она идет на измену. Надо было ждать Грегора». Эта меньшая часть не прощает Абигайл хихиканья по поводу избиения Грегора. Преподаватель в ходе обсуждения обращает внимание студентов на противоречие, связанное с тем, что персонаж, олицетворяющий ценность «любовь» занимает последнюю позицию. В дискуссии студенты по сути проводят структурную операционализацию понятия «любовь», обнаруживая солидарность в поиске операциональных понятий.

Грегор, по мнению опять-таки большинства студентов, ассоциируется с верностью, но защитников у него не много. Большинство не одобряет пассивность Грегора, часть девушек возмущает также то, что он не простил Абигайл. Обсуждение действий Абигайл и Грегора придает дискуссии характер гендерного конфликта между студентами. Преподаватель, регулируя и направляя дискуссию, гасит гендерный конфликт, обращая 
внимание студентов на его культурную обусловленность (Луков, Кириллина, 2005).

Поведение матери вызывает не менее бурные споры. Хотя большинство студентов считает, что мать Абигайл олицетворяет свободу выбоpa (а меньшая часть затрудняется дать ответ на поставленный вопрос), абсолютное большинство считает поведение матери возмутительным, неприемлемым. Ее поведение классифицируют как равнодушное. Наиболее распространенное мнение: «Мать обязана была дать совет, должна была остановить дочь». Единицы считают поведение матери вполне допустимым и даже желательным. И только дважды прозвучали следующие высказывания: «Сейчас почти все возмущаются поведением матери, а в реальности, когда наши матери дают нам советы, вмешиваясь в нашу личную жизнь, мы ссоримся с ними из-за этого».

Синбад. Этот персонаж гораздо реже других занимает верхние строчки рейтинга. Но те, кто определяет его на 1-2 места, аргументируют свою позицию следующим образом: «Каждый живет как может, он не насиловал ее, он только предложил». Большинство студентов данную аргументацию не принимает, возмущенно парирует: «Разве можно пользоваться трудной ситуацией другого человека?» У студентов довольно часто возникают трудности с определением ценности, олицетворяемой Синбадом. Меньшая часть называет в качестве таковой секс. Еще часть студентов ассоциирует с ним корысть. В этих случаях возникает дискуссия, является ли корысть ценностью, что дает возможность вернуться к теории еще раз.

Джон. Как и Синбад, Джон с трудом ассоциируется с какой-либо ценностью. Чаще всего называют честь, уважение женщин, благородство. Другая часть студентов, возмущенная поведением Джона примерно так формулирует свое отношение: «Вмешивается в дела посторонних людей, причем не разобравшись».

После обсуждения рассказа студенты получают домашнее задание: написать свой рассказ с соблюдением нескольких условий. Условия таковы: 1) завязка рассказа сохраняется (Абигайл и Грегор влюблены, мост разрушен, крокодилы буйствуют); 2) героев должно быть 5; 3) проблему нужно решить в идеальном для автора «домашнего» рассказа варианте, Абигайл и Грегор должны встретиться.

К сожалению, при выполнении данного задания условия соблюдают не все. Из 73 рассказов, собранных за 3 года, в анализ включен 61 рассказ. 58 рассказов написано девушками и 3 - юношами. Один из домашних рассказов приведен для примера в тексте. Способ разрешения проблемы в этом рассказе вполне традиционен, но это единственная попытка выполнить домашнее задание в стихотворной форме, принадлежит она Лене Макушкиной (2003-2004 уч. г.). 
«Давным-давно в далекой деревушке

Жила девчонка Абигайл и мать ее старушка.

У Абигайл возлюбленный был,

Грегор, который жил в деревне через реку

А через реку ветхий мостик был,

В реке же жил огромный крокодил.

И вот в один денечек злополучный

Мост рухнул, вместе с планами на будущее.

И, что же делать девушке теперь?

Ведь в той реке живет гигантский зверь!

И девушка к Синбаду-рыбаку

Отправилась развеять всю тоску:

- Синбад, ты помоги в моей беде,

Перевези меня на лодке по реке

В деревню, где живет любимый мой.

- Ты проведешь за это ночь со мной?-

Спросил Синбад, а Абигайл в ответ

Пошла у мамы спрашивать совет.

- Да, ты с ума сошла! - сказала мать.

- Как можешь ты за это ночь отдать?

Тебя ведь Грегор проклянет.

Сиди и жди, когда он сам придет.

А в это время в деревушке за рекой

И Грегора не посещал покой.

Он в лес ходил и дерево искал, Чтоб лодку сделать и увидеть Абигайл.

И вот, когда он руки опустил,

Охотник Джон попался на пути.

Рассказ влюбленного был выслушать не прочь,

И согласился с радостью помочь.

И, после долгих ожиданий у реки,

Влюбленная увидела вдали

В огромной лодке столь знакомый силуэт.

С тех пор счастливей пары в мире нет.

Мораль всей этой сказки такова:

Когда влюбленных разлучают не слова,

А расстояние огромнейшей реки,

Любовь ты эту в сердце береги,

Будь верен ей до самого конца

И пусть предательства не ведают сердца!

В «домашних» рассказах представлены следующие варианты разре- 
шения проблемы:

- Абигайл берет инициативу в свои руки и перебирается к Грегору на другой берег реки (33);

- Грегор переплывает на другой берег к Абигайл (17);

- встреча влюбленных - результат усилий обоих влюбленных (11).

Женщине традиционно предписывалось пассивное поведение в отношениях с мужчиной. В этих же результатах отчетливо проявляются тенденции изменения гендерных стереотипов в части ролей женщин и мужчин. Безусловно, данные проекции не означают, что абсолютно все реализуют свои установки на практике.

Особый интерес в контексте культуры представляет роль матери, коль скоро ее поведение вызвало бурное обсуждение. Анализируя роль матери в «домашних» рассказах студентов, можно сделать вывод, что представления о ней весьма разнообразны. Самой распространенной моделью поведения оказалась помощь матери действием в организации встречи. В четверти рассказов реализована данная модель поведения матери Абигайл. Мать давала деньги на оплату лодки, занимала деньги для оплаты лодки, сама договаривалась с лодочником, нанимала Джона для строительства лодки. В одном рассказе из этого ряда модель поведения матери приобретает характер анекдота: «Мама у Абигайл была очень мужественная и храбрая. И она возмущенно сказала дочери: “Ты будешь сидеть дома, а я поговорю с этим нахалом Синбадом и съезжу с ним за Грегором”. Абигайл всегда прислушивалась к маме, она сказала: “Я буду ждать вас на берегу”. Идеальная мать? Обеспечила желаемое ребенку? Вполне типичная ситуация для нашей культуры.

Еще немногим более $10 \%$ рассказов содержат описание матери как женщины мудрой, давшей дочери совет о том, как попасть на другой берег. Продолжая тематику роли матери как мудрой советчицы дочери, приведу остальные рекомендации:

- «нельзя поступаться своей честью» (5);

- «сиди и жди, если он тебя любит, то что-нибудь придумает» (4);

- «если любишь, то должна бороться за свое счастье» (2).

Немногим менее половины рассказов содержат иные варианты поведения матери Абигайл. Почти четвертая часть рассказов предлагает вариант, когда мать не вмешивается, не дает советов, она просто комментирует события или просто есть. Реакция матери аналогичная той, что была в рассказе-оригинале, имеет место почти в $15 \%$ рассказов. В двух рассказах дочь вообще не обращается к матери за советом. Моделируя поведение матери, студенты проявляют свое отношение к ситуации.

На следующем занятии студентам предлагается прочесть свои рассказы. Это делают только желающие. Дискуссия, как правило, уже не воз- 
никает, но реплики из аудитории иногда слышатся.

Затем следует резюме преподавателя, содержащее сравнительный анализ выполнения практического занятия по группам, анализ изменения гендерных ролей в рамках культуры, здесь же приводятся данные исследований ценностных ориентаций россиян. Студенты в процессе выполнения задания просят преподавателя высказать свою точку зрения, обнародовать свой рейтинг персонажей и прокомментировать. Очевидно, что мнение преподавателя студенты соотносят со своим. У преподавателя возникает масса возможностей обратить внимание студентов на то, что данное задание не может оцениваться по критерию «выполненное правильно / неправильно», на вариативность неформальных социальных норм и т. д.

Что дает выполнение данного практического задания? Студенты имеют возможность осознать свои ценностные ориентации, задуматься о том, как ценностные ориентации влияют на мнения и действия конкретных людей. Кстати, довольно часто (это зависит от уровня подготовки группы) выполнение практического задания служит основанием для перехода к размышлениям о сложности межличностных отношений, проблеме выбора, нормах и отклонениях от них, гендерных конфликтах. Например, переходили к просмотру во внеучебное время различных фильмов известных режиссеров и дальнейшему обсуждению названной проблематики.

Важно также то, что студенты при выполнении подобных заданий имеют возможность, не только получить новые знания о ценностях социальных групп, но и, что называется, «подняться» над собственным жизненным опытом, сравнить его с опытом своих однокурсников. Преподаватель получает очень ценную информацию об аудитории, с которой он работает, имеет возможность скорректировать последующие задания.

\section{СПИСОК ЛИТЕРАТУРЫ}

Луков, Вал. А., Кириллина, В. Н. (2005) Гендерный конфликт: система понятий. // Знание. Понимание. Умение. № 1. С. 86-101.

Петрова, Р. Г (2010) Гендерология и феминология : учебное пособие. 5-е изд., перераб. и доп. М. : Изд-ко-торговая корпорация «Дашков и К». 272 с.

Практикум по социологии : учебно-методические разработки семинарских и практических занятий по курсу «Социология» (2000) / отв. ред. С. Н. Щеглова. М. 
Селиверстова Нина Анатольевна - доктор социологических наук, профессор, профессор кафедры социологии Московского гуманитарного университета. Адрес: 111395, Россия, г. Москва, ул. Юности, д. 5. Тел.: +7 (499) 374-60-21. Эл. адрес: nas0311@ya.ru

Seliverstova Nina Anatolievna, Doctor of Sociology,Professor, Department of Sociology, Moscow University for the Humanities. Postal address: 5 Yunosti St., 111395 Moscow, Russian Federation. Tel.: +7 (499) 374-60-21. E-mail: nas0311@ya.ru 